\title{
OLLEWIDHE \\ DÖ, DIN HUND! \\ Krig, lek och läsning i svensk \\ barnboksutgivning under 200 år
}

\author{
Lund: ellerströms förlag, 2015. Skrifter utgivna av Svenska \\ barnboksinstitutet, nr 129. (366 s.) Diss.
}

Mye av barnelitteraturen som har vendt seg især mot gutter, har hatt krigsleken som et sentralt motiv. Dosent Olle Widhe ved Göteborg Universitet utga i år avhandlingen Dö, din hund! Krig, lek och läsning $i$ svensk barnboksutgivning under $200 \stackrel{a}{a}$. Denne boka favner vidt i sin håndtering av den slags guttebøker. En hovedsak har vært å lese bruken av dette motivet inn i en barndomshistorisk kontekst knyttet til ulike stadier i modernitetens historie, i boka inndelt i den tidlige (1500-1789), den klassiske (1789-1914) og den sene (1914-1989). Framstillingen av kjønn blir selvsagt en hovedsak i bøker som handler om å leke krig. I boka påvises flere interessante nyanser i håndteringen av et vedvarende, maskulint hegemoni.

Widhe har valgt å konsentrere boka om et avgrenset utvalg av bøker og forfattere. Analysene kan slik gi plass til nærlesninger som fanger opp hittil oversette nyanser. Et godt eksempel er hans lesning av Olof Fryxells Snöfästningen. Berättelse för Landt-Gossar fra 1830. Göte Klingberg har lagt vekt på at denne bokas skildring av lekende gutter var skrevet blott til lyst og slik innebar et oppbrudd fra 1700-tallets didaktiske fortellinger for barn. At boka på romantisk vis til dels framstiller barndommen som et privilegert frirom, atskilt fra den voksne verden, blir bekreftet av Widhe. Men samtidig får han fram at måten guttene leker krig på, samsvarer med et ideal for mannlig fostring som var typisk for gøtisismen.

Som kjent var dette en bevegelse som på 1800-tallet, især i Sverige, dyrket fram forestillinger om nordisk storhet i vikingtida, mye basert på islandske sagaer. Tekster fra Esaias Tegnérs diktsyklus Frithiofs Saga (1825-1830) ble raskt inkludert i den svenske skolens lesebøker sammen med ulike typer folkelig tradisjonsgods. Å løfte fram minner om en fortid da nasjonen framsto som fylt av ungdom-

(C)2015 H. Bache-Wiig. This is an Open Access article distributed under the terms of the Creative Commons Attribution-Noncommercial 3.0 Unported License (http://creativecommons.org/ licenses/by-nc/3.0/), permitting all non-commercial use, distribution, and reproduction in any medium, provided the original work is properly cited.

Citation: Barnboken - tidskrift för barnlitteraturforskning/Barnboken - Journal of Children's Literature Research, Vol. 38, 2015 http://dx.doi. org/10.14811/clr.v38i0.215 
melig kraft og uskyld, ga den oppvoksende slekt en felles framtid å tro på og å kjempe for. Snöfüstningen rommer en viss dobbelthet. Den er emansipatorisk, framtidsrettet ved å la bondegutter sloss på like linje med gutter fra høyere stender, alle inkludert i lekens fellesskap. Men regien for leken er ivaretatt av adelsgutten Wilhelm, og utenfor leken, i de voksnes verden, er det ikke noe som tyder på utjevning av samtidas store standsforskjeller.

Ikke overraskende får finlandssvenske Zacharias Topelius en sentral plass i boka. Fortellingene han først skrev for det finske barnebladet Eos (1854-1866), etter hvert tatt inn i diverse samlebind kalt Läsning för barn, fikk utbredelse over hele Norden. Widhe tar for seg hva slags roller som typisk tilskrives gutter og jenter i historier der barn leker krig. Jentene framstilles som bundet til det borgerlige familierommet, opptatt med - også i lek - å innøve voksne ferdigheter. Guttene, derimot, slipper seg modig og villstyrlig løs i selvskapte krigsarenaer utenfor hjemmet. Hos dem er vekten lagt på det subjektive, på opplevelsen av egen mestring eller svikt. De er hver især innrømmet atskillig frihet til å begå alskens guttestreker, men ved samtidig lojalt å slutte seg til et guttefellesskap, oppøves de også til å mestre rollen som voksen mannsperson. Slik Widhe ser det, er mannsidealet som fremmes i Topelius' historier om gutter som leker krig, godt egnet til å videreføre et mannlig hegemoni innenfor et samfunn der borgerskapet får stadig større plass.

Topelius lar det ofte framgå at leken henter næring fra guttenes egen lesning, fra historier om berømte helter, både fiktive og mer historiske. Men her får Widhe fram et paradoks. I flere av Topelius' fortellinger er en leseglad og kontemplativ gutt stilt i sterk kontrast til en handlekraftig kar som ferdes ute og ikke viker unna for virkelighetens utfordringer. Om det ender med knall og fall, står Topelius på villbassens side og lar sin forteller dømme den innesittende bokslukeren: "Ingen klemig gosse blit nogonsin en duktig karl." (s. 119) Et noe uventet budskap fra en person som kanskje mer enn noen annen fremmet leselyst hos barn i Norden!

I andre halvdel av 1800-tallet ble allmenn verneplikt innført i den svensk-norske unionen og tjenestetiden utvidet. Militær disiplin stilt til tjeneste for fedrelandet blir en hovedsak, og æraen for individualisme tilbakelagt i framstilling av gutter og krig. Widhe viser dette i analysen av noen kolorerte bildebøker for små barn. Den ene, Gossens lefonadsåldrar, utkom anonymt på Bonniers i 1861. De syv illustrerte fasene i et gutteliv er alle av det militære slaget. Barnet som leker soldat på omslaget - også på boka til Widhe - har samme slags bart som den fullvoksne major han ender opp som. Militärisk bilderbok för 
gossar (1871) oppøver sine lesere til å vise militær, mannlig disiplin. På hver side fins to bilder: ett av voksne soldater i krig, et annet der gutters krigslek tilsvarer de voksnes militære ferdigheter i krigens ulike faser.

Begrepet "homososial" svarer bra til den type mannlig solidaritet som blir innlært og idealisert i småbarnsbildebøkene om krig utgitt etter 1850. At det dreier seg mer om kjønnsbestemt, krigerisk samhold enn om kamp for det nasjonale, framgår av at de omtalte bøkene er anonyme, uten nasjonalt særpreg. Militürisk bilderbok som var utgitt på tysk i 1869, ble riktignok lett forsvensket. På tegningene gjengitt i 1871, bærer soldatene svenske uniformer og kriger under blågult banner.

Atskillig mer ettertrykk får det nasjonale i barnebøkene Ossian Elgström utga i mellomkrigstida. Bøkene hans ble lansert som guttebøker, men i dem får også søstre, brødre og foreldre stor plass. Gutters utfoldelse som lekende barn har nær tilknytning til familierommet, og ifølge Widhe kan en slik forening av lek, hjem og familie koples til myten om ett folk, én familie som ble viktig i den nazistiske ideologien - som Elgström sluttet seg åpent til på 1930-tallet.

Elgströms første barnebok, Hur man för krig med tennsoldater, utkom høsten 1914 og fikk til dels begeistret mottakelse. Det kan virke merkelig: en brutal verdenskrig var nettopp brutt ut. Men både her og i Elgströms senere bøker om gutter som leker krig, er det lett å falle for hans innskriving av krig i lekens modus. Skal leken tas på alvor, kreves det gjensidig respekt for felles regler, for fair play, av begge de kjempende parter. De muntre og løsslupne krigene Elgström lar guttesoldater utkjempe i bøker fra 1920-åra, er lagt til tida da han selv var i 12-årsalderen. En guttegeneral heter Ossian, som han selv.

En slik idyllisert barnliggjøring og teatralisering av krig mente Johan Huizinga hadde en helt legitim plass innenfor barns lekekultur (Jf. Homo Ludens, 1936). Widhe nevner ham, men mener mentalitetshistorikeren George L. Mosse har et mer dekkende perspektiv. I Fallen Soldiers (1990) undersøker han hva slags svar verdenskrigenes massedød fikk innenfor kunst og kultur. Han hevder at krigens grusomme erfaringer ble trivialisert, gjemt bort bak et slør av humørfylte fortellinger og ved tilbud på alt slags krigsleketøy for barn. Elgström bidrar på flere måter til en slik trivialiserende uskyldiggjøring av krigen, for eksempel i gutteboka Erövringen av staden Babylon (1926). Fortellerteknisk er guttekrigerne framstilt som likeverdige, med samme adgang til leserens empatiske innlevelse. Om de sloss mot hverandre som bedremannsbarn eller bondesønner, inngår de 
alle i et forestilt, nasjonalt fellesskap og fortjener samme slags heder som lojale, redelige og tapre krigere.

Helt annerledes blir kamp og krig framstilt nær 60 år senere i Hans Erik Engqvists Tredagarskriget (1983). Her tjener ikke skildringen av krigsleker til å stadfeste et idyllisk, nasjonalt guttefellesskap. Tvert om, den bidrar til å tydeliggjøre avstanden mellom klasser og livsanskuelser. Også i denne boka, med handlingen lagt til 1951, henter gutter sine scenarioer fra bøker og filmer som heroiserer og mytologiserer krig. Krigen blir gjort til en arena for lek som styrker gutters maskuline selvbilde og dermed trivialisert. Men i Tredagarskriget er effekten annerledes. Jeg-fortelleren, arbeidersønnen Hans Erik, må innse at hans far, kommunisten Gustav, djervt og uselviskt, kjemper en kamp for sosial rettferdighet. Den er av et langt virkeligere og edlere slag enn de krigsbataljer bokas guttegjeng fantaserer fram. I guttenes lek får leseren også kjenne på krigens smerte, vilkårlighet og nederlag. Alt tjener til å avtrivialisere en lese- og lekekultur som har bekreftet et borgerlig, maskulint hegemoni.

I den siste delen av boka peker Widhe mer generelt på ulike tilløp til avvikling av dette hegemoniet slik det har vært virksomt i modernitetens siste to stadier. Viktig her er selvsagt fredsbevegelsen i kjølvannet av den kalde krigen, og kvinnebevegelsen. Barns rett til å utfolde seg autonomt $i$ en verden atskilt fra den voksne, ble mindre selvsagt og romantisert. Skole, barnehage og hjem måtte ta ansvar og sikre at lekene får et innhold som fremmer likestilling og fredelig fellesskap. Faktisk fikk man i Sverige i 1979 innført forbud mot å selge krigsleker som etterliknet våpen tatt i bruk etter 1914.

Uansett, også etter Murens fall har moderne, visuelle medier blottstilt krigens realiteter også for uskyldige barn. Skal bøker, bilder og spill styre unna dette emnet, eller tvert om vise det fram til ettertanke og som advarsel? Sterk debatt om saken pågikk i 1980-åra. Flere anså Bruno Bettelheims The Uses of Enchantment (1976) som et godt, terapeutisk fundert forsvar for å gi krigens onde krefter plass i mytisk-eventyrlige fortellinger rettet mot både jenter og gutter.

Widhe heller selv mot en postmoderne oppfatning, og han viser til pedagogen Charlotte Tullgrens avhandling Den välreglerade friheten. Att konstruera det lekande barnet (2004). I samtidas multimediale miljøer tilrettelegges barnas lek gjerne interaktivt: filmer, bildeblader og dataspill brukes som leketøy. Hva barna seg imellom får ut av denne leken, står åpent. På lik linje med voksne tolker de tegnene i sine egne omgivelser, deltar i kulturen og tar i bruk dens ressurser. Handler leken mye om krig, som i japanske Pokémon, må funksjonen undersøkes i hvert enkelt tilfelle. 
Det som i hvert fall kan fastslås, er at Olle Widhe har publisert en avhandling som er høyst leseverdig, akademisk velorientert og oppdatert. Med stadig nye synsvinkler på et begrenset, men også mangfoldig materiale, får han fram hvordan gutters krigslek, formidlet både litterært og med bilder, bidro til å styrke et maskulint hegemoni. Riktignok kan det innvendes at framdriften stundom svekkes av de mange lærde sideblikk og referanser, og overgangen til en postmoderne æra kunne nok vært skarpere profilert. Men likevel, en særlig styrke ved boka er forfatterens sans for paradokser: Nostalgisk dyrking av fortida skaper tro på framtida. Å mytologisere krigen og dens edle kamper, trivialiserer den. Og, ikke minst, bokas mange fargestrålende illustrasjoner, deriblant den muntre kollasjen på forsida, bidrar til en lystfylt leseopplevelse tross all dens akademisk tyngde.

Harald Bache-Wiig

Professor i nordisk litteraturvetenskap Institutt for lingvistiske og nordiske studier

Universitetet i Oslo 